\title{
Diversity Among Strains of Xanthomonas campestris pv. vitians from Lettuce
}

\author{
F. Sahin, P. A. Abbasi, M. L. Lewis Ivey, J. Zhang, and S. A. Miller
}

The Ohio State University, OARDC, 1680 Madison Avenue, Wooster 44691.

Current address of F. Sahin: Ataturk University, College of Agriculture, Department of Plant Protection, Erzurum 25240, Turkey.

Current address of P. A. Abbasi: Southern Crop Protection and Food Research Center, Agriculture and Agri-Food Canada, 1391 Sandford

St., London, ON N5V 4T3, Canada.

Accepted for publication 19 August 2002.

\section{ABSTRACT}

Sahin, F., Abbasi, P. A., Lewis Ivey, M. L., Zhang, J., and Miller, S. A. 2003. Diversity among strains of Xanthomonas campestris pv. vitians from lettuce. Phytopathology 93:64-70.

Diversity in host range, pathogenicity, phenotypic characteristics, repetitive extragenic palindromic polymerase chain reaction (rep-PCR) profiles, and sequence of the 16S-23S rDNA spacer region was examined among 44 Xanthomonas strains isolated from lettuce. Forty-two of the strains were divided into two groups, designated A and B. Seventy percent were Group A, and most of the remaining strains including a reference strain (LMG 938) were Group B. Group A strains induced both local and systemic symptoms, whereas Group B strains caused only distinct necrotic spots. Two strains, including the $X$. campestris pv. vitians type strain, were distinct from the Group A and B strains and were not pathogenic on lettuce. Analysis of fatty acid profiles, serotype, carbon substrate utilization patterns, and protein fingerprints confirmed this grouping. The Group A and B strains also formed two unique clusters (I and II) by rep-PCR profiling that corresponded to the two groups. Direct sequencing of a PCR-amplified DNA fragment (680 bp) from the 16S23S rDNA spacer region of four representative strains, however, did not differentiate these groups. Serology and rep-PCR fingerprinting can be used to diagnose and identify $X$. campestris pv. vitians strains, while the other analyses evaluated are useful for strain characterization.
Bacterial leaf spot, caused by Xanthomonas campestris pv. vitians (Brown) Dye, is an important pathogen of lettuce (Lactuca sativa L.) worldwide. Since 1995, serious outbreaks of the disease have occurred on lettuce cultivars grown in Ohio (16). Two types of symptoms are exhibited on lettuce: (i) localized necrotic spots scattered on the leaf surfaces; and (ii) systemic infection starting with dark brown, water-soaked lesions along the margin of leaves that expand toward leaf veins and result in V-shaped lesions or dieback (16). X. campestris pv. vitians strains also cause necrotic spots on pepper (Capsicum annuum L.) and tomato (Lycopersicon esculentum Mill.) (17).

Studies comparing pathogenicity type on lettuce with phenotypic and genotypic characteristics among $X$. campestris pv. vitians strains have not been reported. Stefani et al. (22) and Yang et al. (29) divided $X$. campestris pv. vitians strains into two groups based on sodium dodecyl sulfate polyacrylamide gel electrophoresis (SDS-PAGE) and fatty acid methyl ester (FAME) analysis, respectively. In both cases, the majority of the strains tested fell into one group, with a smaller group containing the pathovar-type strain LMG 937. Vauterin et al. (24) proposed on the basis of DNA hybridization and metabolic fingerprinting (Biolog) data that $X$. campestris pv. vitians be separated into two species: $X$. axonopodis pv. vitians, including the pathovar type strain LMG 937, and $X$. hortorum pv. vitians, including the reference strain LMG 938. This separation was later supported by repetitive extragenic palindromic (rep-PCR) fingerprinting analysis (25). However, the studies were carried out with a small number of strains and could not assess the full range of variability in populations of these pathovars. Additional techniques, such as serology and

Corresponding author: S. A. Miller; E-mail address: miller.769@osu.edu

Publication no. P-2002-1021-01R

(C) 2003 The American Phytopathological Society amplification and sequencing of the rDNA spacer region have shown potential for estimating diversity within and between many Xanthomonas species and pathovars $(2,3,12-14,21)$. The objectives of this study were to: (i) characterize $X$. campestris pv. vitians strains isolated from lettuce on the basis of biochemical, physiological, pathological, serological, and molecular criteria; and (ii) determine methods that may be useful for differentiation of X. campestris pv. vitians from other Xanthomonas species.

\section{MATERIALS AND METHODS}

Bacterial strains, culture conditions, and media. Bacterial strains (Table 1) were isolated and identified as described previously (16). All strains were grown on yeast dextrose calcium carbonate (YDC) agar medium (10) at $27^{\circ} \mathrm{C}$ for $48 \mathrm{~h}$ and stored in sterile water at $15^{\circ} \mathrm{C}$ and in $15 \%$ glycerol at $-80^{\circ} \mathrm{C}$. All of the tests described below were done at least twice for all strains.

Pathogenicity and host range. All $X$. campestris pv. vitians strains were tested for pathogenicity as described previously (16) on lettuce (cv. Darkland), pepper (cv. Marengo), tomato (cv. OH88119), cabbage (Brassica oleracea L. var. capitata), kale and collard (B. oleracea L. var. acephala), radish (Raphanus sativus L. cv. Fuego), and horseradish (Armoracia rusticana P. Gaertn., B. Mey. \& Scherb), all natural hosts of Xanthomonas species $(11,23)$. Representative strains of $X$. campestris pv. vesicatoria and $X$. campestris pv. armoraciae pathogenic on pepper and tomato and pepper, tomato, cabbage, and radish, respectively, were used as positive controls. Inoculated plants were incubated in a greenhouse at 25 to $28^{\circ} \mathrm{C}$ and evaluated for characteristic local symptoms after 10 days and again 8 weeks later to assess systemic disease development as described previously (16).

Starch hydrolysis and pectate degradation. All 44 strains of $X$. campestris pv. vitians were tested for the ability to hydrolyze starch and degrade pectin as described by Bouzar et al. (3). 
Serotyping. All $44 X$. campestris pv. vitians strains were tested against a panel of 16 monoclonal antibodies (MAbs) in indirect enzyme-linked immunosorbent assay (ELISA) (3). Antibodies were provided by J. B. Jones (University of Florida) and A. M. Alvarez (University of Hawaii). The MAbs Xv1, Xv5, Xv6, Xv8, $\mathrm{Xv10}, \mathrm{Xv15}, \mathrm{Xv21}$, and Xv30 were developed using $X$. campestris pv. vesicatoria as an immunogen (3). MAbs X9, X13, $\mathrm{X} 17, \mathrm{X} 21$, A11, and B35 were reported to be specific to X. campestris pv. campestris and/or X. campestris pv. armoraciae, while MAbs X1 and X11 were Xanthomonas genus-specific (2). Eight of the sixteen MAbs (Xv5, Xv6, Xv8, Xv10, X1, X11, A11, and B35) reacted with one or more strains. Representative strains of other Xanthomonas species (Table 1) were also tested with these eight MAbs.

Fatty acid methyl ester (FAME) analysis. Whole-cell fatty acids were extracted and methylated as described by Sasser (19). FAMEs were separated by gas chromatography (HP5898A, Hewlett Packard, Palo Alto, CA). FAME profiles were identified using the commercial trypticase soy broth agar (TSBA) database with the Microbial Identification System software package (MIS version 3.8, Microbial ID, Inc., Newark, DE). FAME composition data were evaluated statistically using analysis of variance (ANOVA), and differences among means for the fatty acids in each group were determined by calculating Fisher's protected least significant difference test at $P<0.05$.

Carbon substrate utilization. The Biolog GN microplate system was used according to the manufacturer's instructions (Biolog Inc., Hayward, CA) to test for utilization of 95 compounds as sole carbon sources by 39 strains of $X$. campestris pv. vitians (California strains not tested). The color reaction, indicating positive utilization of each carbon substrate was determined visually. The results (metabolic fingerprint) for each bacterial strain were analyzed using the Biolog GN database with the Microlog Software (Biolog, release 3.01).

SDS-PAGE of proteins. Bacterial strains were grown on YDC medium at $27^{\circ} \mathrm{C}$ for $48 \mathrm{~h}$. Cells harvested from plates were suspended in sterile deionized water and washed twice by centrifugation. Approximately $25 \mathrm{mg}$ of the resulting pellet for each bacterial strain was used for extraction and electrophoresis of total proteins using SDS-PAGE (28).

Rep-PCR genomic fingerprinting. Bacterial strains were fingerprinted using rep-PCR and the consensus primers BOXA1R (5'-CTACGGCAAGGCGACGCTGACG-3'), enterobacterial repetitive intergenic consensus (ERIC)1R (5'-ATGTAAGCTCCTG-
GGGATTCAC-3') and ERIC2 (5'-AAGTAAGTGACTGGGGTGAGCG-3'), and repetitive extragenic palindromic (REP)1R-I ( $5^{\prime}$ IIIICGICGICATCIGGC-3') and REP2-I (5'-ICGICTTATCIGGCCTAC-3') $(13,14)$. Template DNA was purified using a cetyltrimethylammonium bromide (CTAB) solution (2\% CTAB, $1.4 \mathrm{M} \mathrm{NaCl}, 100 \mathrm{mM}$ Tris- $\mathrm{HCl}$ [pH 8], and $20 \mathrm{mM}$ EDTA) followed by a chloroform/isoamyl alcohol (24:1) extraction. DNA was recovered by isopropanol precipitation, redissolved in TrisEDTA (TE) (10 mM Tris, $1 \mathrm{mM}$ EDTA [pH 8]), quantified by spectrophotometry, and diluted to $20 \mathrm{ng} / \mu \mathrm{l}$ (18). Rep-PCR was carried out using the amplification methods and programs described by Louws et al. (12). Amplifications were performed in a thermocycler (Amplitron II, Thermolyne, Dubuque, IA). Sixmicroliter portions of amplified PCR products were separated by horizontal gel electrophoresis on $1.5 \%$ agarose gels in $0.5 \times$ Trisborate-EDTA (TBE) buffer (18) for $120 \mathrm{~min}$ at $70 \mathrm{~V}$, stained with dilute ethidium bromide $(1 \mu \mathrm{g} / \mathrm{ml})$ and visualized using the NightHawk Image Analysis System (pdi, Huntington Station, NY). Normalization of the resulting banding patterns and cluster analyses (Dice Coefficient and Weighted Average Linkage) were performed using Diversity Database software (version 1.0) accompanying the NightHawk Image Analysis System.

Amplification and sequencing of the 16S-23S rDNA spacer region. The $16 \mathrm{~S}-23 \mathrm{~S}$ rDNA spacer region of the bacterial strains was amplified by PCR using the oligonucleotide primers $4 \mathrm{~F}\left(5^{\prime}\right.$ GGCTTGGATCACCTCCTT-3') and 7R (5'-GGTTACCTTAGATGTTTCAGTTTC-3') (7). The 4F and 7R primer sequences correspond to positions 1525 to 1541 in $16 \mathrm{~S}$ rDNA and 188 to 208 in $23 \mathrm{~S}$ rDNA of Escherichia coli, respectively (4,7). PCR amplification of the target sequences was carried out according to the protocol described by Laguerre et al. (9). The amplified DNA products were detected as described above, and analyzed for length polymorphisms. The amplified PCR products from the representative strains LMG 937, 700a, 701a, and LMG 938 were purified using QIAquick PCR purification kits (Qiagen Inc., Chatsworth, CA) according to the manufacturer's instructions. Direct sequencing of purified amplification products was performed twice at the Plant-Microbe Genomics Facility, The Ohio State University, Columbus, OH. Base calling and sequence quality were determined for both strands of the sequences generated using the software Phred $(5,6)$. The software Sequencher (Sequencher 3.0, Gene Codes Corporation, Ann Arbor, MI) was used to assemble, edit, and generate sequences. Sequence alignments were performed and similarity values were calculated with

TABLE 1. Strains of Xanthomonas species and pathovars

\begin{tabular}{|c|c|c|c|}
\hline Pathogen/strain & Host & Location/year isolated & Source or reference \\
\hline \multicolumn{4}{|l|}{$X$. campestris pv. vitians } \\
\hline 700a, 700b, 700c, 700d, 700e, 700f, 701a, 701b, 701c, 701d, 701e, 701f & Lettuce & $\mathrm{OH}, 1995$ & This study \\
\hline $\begin{array}{l}705 \mathrm{a}, 705 \mathrm{~b}, 705 \mathrm{c}, 705 \mathrm{~d}, 906,907,908,909,910,911,912,913,914,915,916 \\
917,918,919,920,921,922,923,924,925\end{array}$ & Lettuce & OH, 1996 & This study \\
\hline B-54 & Lettuce & CA, 1991 & C. Kurowski ${ }^{y}$ \\
\hline B-55 & Lettuce & CA, 1994 & C. Kurowski \\
\hline B-57 & Lettuce & CA, 1996 & C. Kurowski \\
\hline B-59 & Lettuce & CA, 1997 & C. Kurowski \\
\hline Xanthomonas sp. B-53 & Lettuce & CA, 1991 & C. Kurowski \\
\hline X. campestris pv. vesicatoria (Group B) 766A & Tomato & $\mathrm{OH}, 1995$ & This study \\
\hline \multicolumn{4}{|l|}{$X$. campestris pv. vesicatoria (Group A) } \\
\hline $110 \mathrm{c}$ & Pepper & $\mathrm{OH}, 1995$ & This study \\
\hline $762 b$ & Tomato & $\mathrm{OH}, 1995$ & This study \\
\hline X. campestris pv. campestris 702a & Cabbage & $\mathrm{OH}, 1995$ & This study \\
\hline$X$ campestris pv. armoraciae $704 \mathrm{~b}$ & Radish & $\mathrm{OH}, 1995$ & This study \\
\hline
\end{tabular}

y C. Kurowski, Harris Moran Seed Company, San Juan Bautista.

${ }^{\mathrm{z}}$ Received as X. campestris pv. vitians type strain. ATCC = American Type Culture Collection, 12301 Parklawn Drive, Rockville, Maryland 20852; LMG = Collection of the Laboratorium voor Microbiologie en Microbiele Genetica, Rijksuniversiteit, Ledeganckstraat 35, B-9000 Gent, Belgium; NCPPB = National Collection of Plant Pathogenic Bacteria, Central Science Laboratory, Ministry of Agriculture, Fisheries and Food, Sand Hutton, York, Y04 1LW, UK. 
the ClustalW algorithm in Mac Vector (Mac Vector 6.1, Oxford Molecular Ltd., Beaverton, OR) using default settings. GenBank, EMBL, DDBJ, and PDB databases were searched for sequence similarities using Gapped BLAST and PSI-BLAST programs (1).

Phenetic analysis. Genetic relationships among $X$. campestris pv. vitians strains based on rep-PCR DNA fingerprints were determined by cluster analysis. Analysis was performed on combined ERIC, BOXA, and REP data sets. Bands from each gel were scored as present (1) or absent (0) and the resulting data matrix was analyzed by Minitab statistical software version 13.0 (Minitab Inc., State College, PA). Cluster analysis was performed with complete linkage and Euclidean distance option of the software. A dendrogram was also included in the package.

Nucleotide sequence accession numbers. The 16S-23S rDNA sequences of $X$. campestris pv. vitians strains LMG 938, LMG 937, 700a, and 701a have been deposited in the GenBank nucleic acid sequence database under the accession numbers AF537207, AF060175, AF060176, and AF060177, respectively.

\section{RESULTS}

Pathogenicity and host range. $X$. campestris pv. vitians strains were not pathogenic on cabbage, kale, collard, radish, horseradish, or zinnia, but caused necrotic lesions on pepper, tomato, and lettuce (Table 2). Two groups (A and B) were identified based on disease reaction on a group of plant species. Most (70\%) X. campestris pv. vitians strains, which were all isolated from lettuce in Ohio, were placed in Group A. These strains caused local and systemic disease on inoculated leaves and blight on stem and flower branches (16). Most of the remaining strains (25\%), including six Ohio, four California and one reference strain (LMG $938=($ NCPPB 2248), were placed in Group B. These strains induced water-soaked necrotic spots on lettuce leaves (cv. Darkland), but failed to cause a systemic infection. The strains LMG 937 (NCPPB $976=$ ATCC 19320) and B-53 did not cause symptoms on lettuce. None of the tested strains of other Xanthomonas species and $X$. campestris pathovars, including $X$. campestris pv. vesicatoria, $X$. campestris pv. campestris, and $X$. campestris pv. armoraciae were pathogenic on lettuce.

Starch hydrolysis and pectate degradation. All X. campestris pv. vitians pathogenicity Group A and B strains tested were nonamylolytic and weakly pectolytic. Strains LMG 937 and B-53 were amylolytic and nonpectolytic.

Serotype. All $X$. campestris pv. vitians strains reacted with Xanthomonas genus-specific MAbs $\mathrm{X} 1$ and $\mathrm{X} 11$, but varied in their reaction with MAbs Xv5, Xv6, Xv8, Xv10, A11, and B35 (Table 3). Two serological groups were identified and designated serovars A and B. These serovars corresponded to the two pathological groups identified (Table 3). LMG 937 and B-53 reacted only with MAbs X1 and X11. Most of the strains (72\%) reacted with seven of eight MAbs tested (Xv6, Xv8, Xv10, X1, X11, A11, and B35), and were placed in serovar A. The remaining strains reacted with all eight MAbs and were assigned to serovar $\mathrm{B}$. The serological profiles of the strains representing the other Xanthomonas species tested were different from those of $X$. campestris pv. vitians (Table 3).

FAME analysis. $X$. campestris pv. vitians strains contained more than 30 fatty acids, seven of which (14:0, 15:0 iso, 15:0 anteiso, 15:0, 16:0 iso, 16:1 $\omega 7 \mathrm{c}$ and 16:0) were present in all strains with more than $1 \%$ of the total named peak area. No qualitative differences in FAME profiles were observed, but differences in the amount of the seven major fatty acids present were found (Table 4). Pathogenicity Group B strains had significantly more $15: 0$ iso $(24 \%)$ and $15: 0(1.8 \%)$, and less $16: 0$ iso $(2.4 \%)$

TABLE 2. Pathogenicity of strains of Xanthomonas spp. on lettuce, pepper, tomato, cabbage, kale, radish, and horseradish

\begin{tabular}{|c|c|c|c|c|c|c|c|c|c|c|}
\hline \multirow[b]{2}{*}{ Pathovar/strain } & \multirow{2}{*}{$\begin{array}{l}\text { Pathogenicity } \\
\text { group }\end{array}$} & \multicolumn{2}{|c|}{ Lettuce } & \multirow[b]{2}{*}{ Pepper } & \multirow[b]{2}{*}{ Tomato } & \multirow[b]{2}{*}{ Cabbage } & \multirow[b]{2}{*}{ Kale } & \multirow[b]{2}{*}{ Collard } & \multirow[b]{2}{*}{ Radish } & \multirow[b]{2}{*}{ Horseradish } \\
\hline & & Leaves & Stem & & & & & & & \\
\hline \multicolumn{11}{|l|}{ X.campestris pv. vitians } \\
\hline $\begin{array}{l}\text { 700a, 700b, 700c, 700d, 700e, 700f, } \\
\text { 705a, 705b, 705c, 705d, 705e, 906, } \\
\text { 907, 908, 909, 910, 911, 912, 913, } \\
\text { 914, 915, 916,917, 918, 919, 920, } \\
921,922,923,924,925\end{array}$ & A & $\mathrm{N}, \mathrm{S}^{\mathrm{z}}$ & Blight & $\mathrm{N}$ & $\mathrm{N}$ & - & - & - & - & - \\
\hline $\begin{array}{l}\text { 701a, 701b, 701c, 701d, 701e, 701f, } \\
\text { B-54, B-55, B-57, B-59, LMG } 938\end{array}$ & B & $\mathrm{N}$ & - & $\mathrm{N}$ & $\mathrm{N}$ & - & - & - & - & - \\
\hline \multicolumn{11}{|l|}{ Xanthomonas spp. from lettuce } \\
\hline LMG 937 & & - & - & $+/-$ & $+/-$ & - & - & - & - & - \\
\hline B-53 & & - & - & - & - & - & - & - & - & - \\
\hline \multicolumn{11}{|l|}{ X. campestris pv. vesicatoria } \\
\hline $110 \mathrm{c}, 762 \mathrm{~b}$ & & - & - & $\mathrm{N}$ & $\mathrm{N}$ & - & - & - & - & - \\
\hline $766 \mathrm{a}$ & & - & - & - & $\mathrm{N}$ & - & - & - & - & - \\
\hline X. campestris pv. campestris, $702 \mathrm{a}$ & & - & - & - & - & $\mathrm{S}$ & $\mathrm{S}$ & $\mathrm{S}$ & $\mathrm{S}$ & NT \\
\hline X. campestris pv. armoraciae, $704 \mathrm{~b}$ & & - & - & - & $\mathrm{N}$ & $\mathrm{N}$ & $\mathrm{N}$ & $\mathrm{N}$ & $\mathrm{N}$ & $\mathrm{N}$ \\
\hline
\end{tabular}

${ }^{z}$ Symptoms: $\mathrm{N}=$ necrotic lesions; $\mathrm{S}=$ systemic disease; $-=$ no symptoms; +/- = few small necrotic spots; and NT = not tested.

TABLE 3. Reactivity of strains of Xanthomonas spp. with monoclonal antibodies in indirect enzyme-linked immunosorbent assay

\begin{tabular}{|c|c|c|c|c|c|c|c|c|c|c|c|}
\hline \multirow[b]{2}{*}{ Species } & \multirow{2}{*}{$\begin{array}{l}\text { Number } \\
\text { of strains }\end{array}$} & \multirow{2}{*}{$\begin{array}{l}\text { Pathogenicity } \\
\text { group }\end{array}$} & \multirow[b]{2}{*}{ Serovar } & \multicolumn{8}{|c|}{ Monoclonal Antibodyy } \\
\hline & & & & $\mathrm{X} 1$ & $\mathrm{X} 11$ & $\mathrm{Xv5}$ & Xv6 & Xv8 & $\mathrm{Xv10}$ & A11 & B35 \\
\hline \multirow[t]{2}{*}{ X. campestris pv. vitians } & 31 & A & A & + & + & - & + & + & + & + & + \\
\hline & 11 & B & B & + & + & + & + & + & + & + & + \\
\hline Xanthomonas spp. from lettuce ${ }^{\mathrm{z}}$ & 2 & - & - & + & + & - & - & - & - & - & - \\
\hline X. campestris pv. vesicatoria (Group A) & 2 & & & + & + & + & + & - & + & + & - \\
\hline X. campestris pv. vesicatoria (Group B) & 1 & & & - & + & - & - & - & - & - & - \\
\hline X. campestris pv. campestris & 1 & & & + & + & + & - & + & + & + & + \\
\hline X. campestris pv. armoraciae & 1 & & & + & + & + & - & + & + & + & + \\
\hline
\end{tabular}

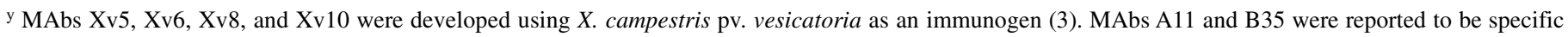
to $X$. campestris pv. campestris and/or X. campestris pv. armoraciae, while MAbs X1 and X11 were Xanthomonas genus-specific (2).

${ }^{z}$ Strains LMG 937 and B-53. 
fatty acids than Group A strains. The ratios of 15:0 iso/16:1 $\omega 7 \mathrm{c}$ and 15:0 anteiso/16:0 for Group A and B strains were approximately 1 and 4 . The proportion of all seven major fatty acids in strains LMG 937 and B-53, averaged together, differed significantly from the proportion of these fatty acids in Groups A and B strains. The ratios of 15:0 iso/16:1 $\omega 7 \mathrm{c}$ and 15:0 anteiso/16:0 for these strains were 1.5 and 1.

Carbon substrate utilization. All $39 X$. campestris pv. vitians strains tested for carbon substrate utilization in the Biolog GN microplate assay system were identified at the species level as $X$. campestris. Only $41 \%$ of the strains were placed in the pathovar vitians. None of the strains metabolized cyclodextrin, $N$-acetyl-Dgalactosamine, adonitol, D-arabitol, $i$-erythritol, $m$-inositol, Lrhamnose, D-sorbitol, xylitol, D-galactonic acid, lactone, D-galacturonic acid, D-glucosaminic acid, D-gluconic acid, $\beta$-hydroxybutyric acid, $\gamma$-hydroxybutyric acid, $p$-hydroxyphenylacetic acid, itaconic acid, D- and L-lactic acid, glucuronamide, L-ornithine, thymidine, phenylethylamine and 2,3-butanediol. However, all strains utilized dextrin, glycogen, Tween 40, Tween 80, $\mathrm{N}$-acetylD-glucosamine, cellobiose, D-fructose, L-fucose, D-galactose, gentiobiose, $\alpha$-D-glucose, lactulose, maltose, D-mannose, D-psicose, sucrose, D-trehalose, turanose, methylpyruvate, monomethylsuccinate, acetic acid, cis-aconitic acid, $\alpha$-ketoglutaric acid, $\alpha$-ketovaleric acid, D-saccharic acid, succinic acid, bromosuccinic acid, succinamic acid, alaniamide, D-alanine, L-alanine, L-alanylglycine, L-aspartic acid, L-glutamic acid, glycyl-L-glutamic acid, glucose 1-phosphate, and glucose 6-phosphate as carbon sources. Utilization of the remaining 34 carbon sources varied. Strains in Groups A and B were differentiated from each other based on differences in utilization of three carbon sources (Table 5). LMG 937 did not metabolize D-melibiose and D-raffinose, which were utilized by Group A and B strains. It did utilize $\alpha$-Dlactose, formic acid, $\alpha$-hydroxybutyric acid, $\alpha$-ketobutyric acid, glycyl-L-aspartic acid, L-serine, L-threonine and glycerol.

TABLE 4. Variable fatty acids among Xanthomonas campestris pv. vitians (Groups A and B) and Xanthomonas spp. (type strain LMG 937 and B-53) strains, isolated from lettuce and identified using fatty acid methyl ester (FAME) analysis

\begin{tabular}{lrrrr}
\hline & \multicolumn{4}{c}{ Fatty acid concentration (\%) } \\
\cline { 2 - 5 } Fatty acid & Group A & Group B & LMG 937/B-53 & LSD $^{\mathrm{y}}$ \\
\hline 14:0 & $1.1 \mathrm{~b}^{\mathrm{z}}$ & $1.7 \mathrm{~b}$ & $2.4 \mathrm{a}$ & 0.48 \\
$15: 0$ iso & $19.4 \mathrm{~b}$ & $23.6 \mathrm{c}$ & $30.4 \mathrm{a}$ & 2.43 \\
$15: 0$ anteiso & $14.2 \mathrm{~b}$ & $15.7 \mathrm{~b}$ & $8.1 \mathrm{a}$ & 2.51 \\
$15: 0$ & $1.3 \mathrm{~b}$ & $1.8 \mathrm{c}$ & $3.1 \mathrm{a}$ & 0.37 \\
$16: 0$ iso & $2.9 \mathrm{~b}$ & $2.4 \mathrm{c}$ & $4.8 \mathrm{a}$ & 0.42 \\
$16: 1 \omega 7 \mathrm{c}$ & $23.3 \mathrm{~b}$ & $23.9 \mathrm{~b}$ & $20.8 \mathrm{a}$ & 1.99 \\
$16: 0$ & $3.8 \mathrm{~b}$ & $4.2 \mathrm{~b}$ & $7.9 \mathrm{a}$ & 1.28 \\
\hline
\end{tabular}

${ }^{y}$ Least significant difference at $P<0.05$ calculated using Fisher's protected least significant difference test.

${ }^{\mathrm{z}}$ Means in a row followed by the same letter are not significantly different at $P<0.05$.

TABLE 5. Differences among Xanthomonas campestris pv. vitians and Xanthomonas sp. strains, isolated from lettuce, in utilization of carbon sources in the Biolog GN microplate assay

\begin{tabular}{lcccc}
\hline & \multicolumn{2}{c}{ X. campestris pv. vitians } & & Xanthomonas sp. \\
\cline { 2 - 3 } Carbon substrate & Group A & Group B & LMG 937 \\
\hline$\alpha$-D-Lactose & - & - & + \\
D-Melibiose & + & + & - \\
D-Raffinose & + & + & - \\
Formic acid & - & - & + \\
$\alpha$-Hydroxybutyric acid & - & + & + \\
$\alpha-$-Ketobutyric acid & - & + & + \\
Glycyl-L-aspartic acid & - & - & + \\
L-Serine & + & - & + \\
L-Threonine & - & - & + \\
Glycerol & - & - & + \\
\hline
\end{tabular}

SDS-PAGE of proteins. SDS-PAGE protein profiles of the selected strains tested included more than 40 reproducible bands of molecular weight ranging from 10 to more than $100 \mathrm{kDa}$ (Fig. 1). Protein profiles for strains in each group were distinct from one another. Except for a $20-\mathrm{kDa}$ band present only in two Group A strains, protein profiles among the strains of each group were homogeneous. The protein fingerprints of Group A and B strains differed in two low molecular weight bands (26.6 and $27 \mathrm{kDa})$. A 26.6-kDa band was present in Group A but not in Group B. Similarly, a $27-\mathrm{kDa}$ band was absent in Group A but present in Group B. Strains LMG 937 and B-53 displayed a unique banding pattern distinct from those of $X$. campestris pv. vitians Group A and B strains. Protein profiles of $X$. campestris pv. vitians Group $\mathrm{A}$ and $\mathrm{B}$ strains were dissimilar to profiles of $X$. campestris $\mathrm{pv}$. vesicatoria strains.

Rep-PCR fingerprinting. Rep-PCR using BOXA, ERIC, and REP consensus primers generated complex fingerprint patterns consisting of 12 or more distinct bands ranging in size from $0.2 \mathrm{~kb}$ to approximately $4 \mathrm{~kb}$. Group A and B strains of $X$. campestris pv. vitians formed unique banding patterns (Fig. 2) resulting in the two distinct clusters I and II (Fig. 3). Group A strains were 85\% similar while strains in Group B had similarity of $76 \%$. The similarity between Groups A and B was 70\%. Strains LMG 937 and B-53 had somewhat similar banding patterns and were clustered together with $X$. campestris pv. vesicatoria strain 110c. These strains were not closely related to the Group A and B strains ( $31 \%$ similarity). The $X$. campestris pv. vesicatoria strains were readily separated from all strains of $X$. campestris pv. vitians (Fig. 2).

Amplification and sequencing of the 16S-23S rDNA spacer region. All strains of $X$. campestris pv. vitians and six other $X$. campestris pathovars contained a single spacer region. Direct sequencing of the PCR product from strains LMG 938, 700a, and 701a showed no sequence differences in this region, but similarity of these strains with LMG 937 was 95\% (Fig. 4). Comparisons of these sequences with GenBank, EMBL, DDBJ, and PDB databases (1) showed that the 16S-23S rDNA spacer regions of the $X$. campestris pv. vitians strains and LMG 937 contain the transfer RNA (tRNA) genes tRNA ${ }^{\text {Ala }}$ and tRNA ${ }^{\text {Ile }}$.

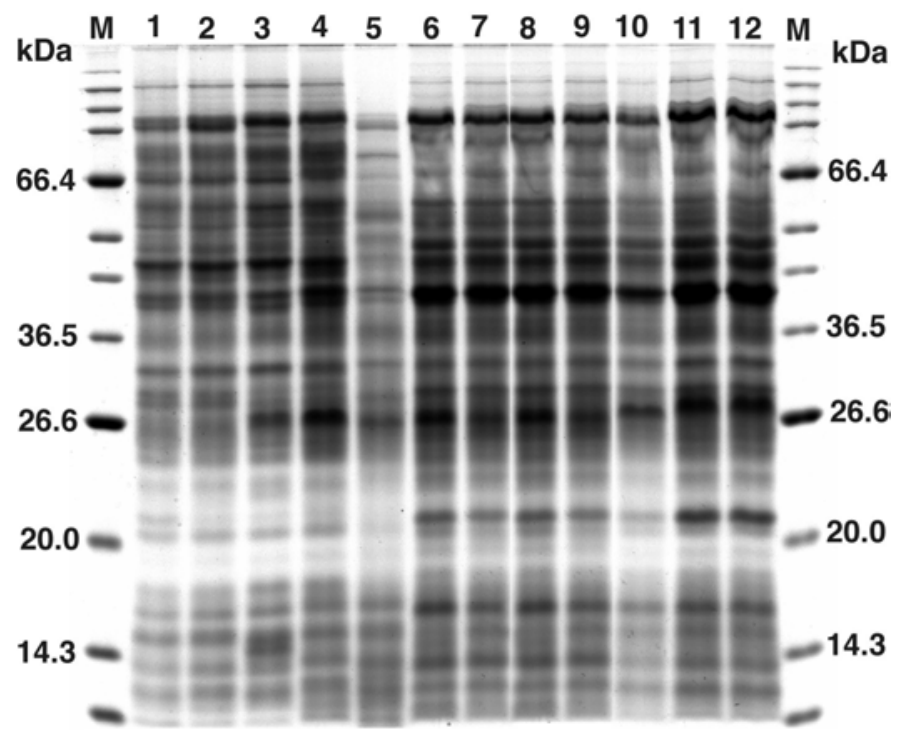

Fig. 1. Sodium dodecyl sulfate-polyacrylamide gel electrophoresis profiles of Xanthomonas campestris pv. vesicatoria and $X$. campestris pv. vitians strains. Lanes 1-3, X. campestris pv. vesicatoria strain 110c (Group A), strain 766a (Group B), and strain 762b (Group B), respectively; lane 4, Xanthomonas sp. B-53 (nonpathogenic strain); lane 5, X. campestris pv. vitians type strain (LMG 937); lanes 6-9, X. campestris pv. vitians Group A strains (700a, 700b, 705a, and 916); lanes 10-12, X. campestris pv. vitians Group B strains (LMG 938, 701a, and 701c; and M = protein marker (broad range, 2$212 \mathrm{kDa})$. 


\section{DISCUSSION}

This study confirms our previous report (17) of an expanded host range of $X$. campestris pv. vitians. Our strains were pathogenic on lettuce, pepper, and tomato, but not on cabbage, kale, collard, radish, and horseradish. None of the other Xanthomonas species and pathovars tested (X. campestris pvs. vesicatoria, campestris, and armoraciae) caused symptoms on lettuce. Strains of $X$. campestris pv. vitians were separated into two groups (A and B) based on differential disease phenotype on lettuce. This separation was supported by monoclonal antibody, FAME, carbon substrate utilization, SDS-PAGE of proteins, and rep-PCR analysis. Group A strains caused necrotic spots and systemic disease, while Group B strains induced necrotic spots only. The pathovar type strain for $X$. campestris pv. vitians, LMG 937, and California strain B-53, both isolated from lettuce, did not cause symptoms on 'Darkland'. This is the first report of pathogenic variation among $X$. campestris pv. vitians strains. Previous studies consistently divided $X$. campestris pv. vitians into two groups based on molecular or biochemical characteristics $(22,24,27,29)$. The groups consisted of a larger group including the pathovar reference strain LMG 938 and a smaller one containing LMG 937. In this study, LMG 937 was weakly pathogenic, producing a small number of necrotic spots on tomato and pepper but failed to induce symptoms on lettuce. Stefani et al. (22) also reported that LMG 937 was nonpathogenic on lettuce. This introduces the possibility that the pathovar type strain of $X$. campestris $\mathrm{pv}$. vitians was misidentified or mislabeled, or that this particular strain isolated in 1917 lost pathogenicity on lettuce after many years in culture. In this study, reactivity with a panel of monoclonal antibodies and rep-PCR clearly differentiated LMG 937 from $X$. campestris pv. vesicatoria. Although Rademaker (15) grouped LMG 937 in the $X$. axonopodis cluster 9.5 by rep-PCR, it was distinct from $X$. campestris pv. vesicatoria (cluster 9.2) (X. axonopodis pv. campestris). LMG 937 was most closely related to $X$. axonopodis pv. malvacearum. It is possible that LMG 937 is

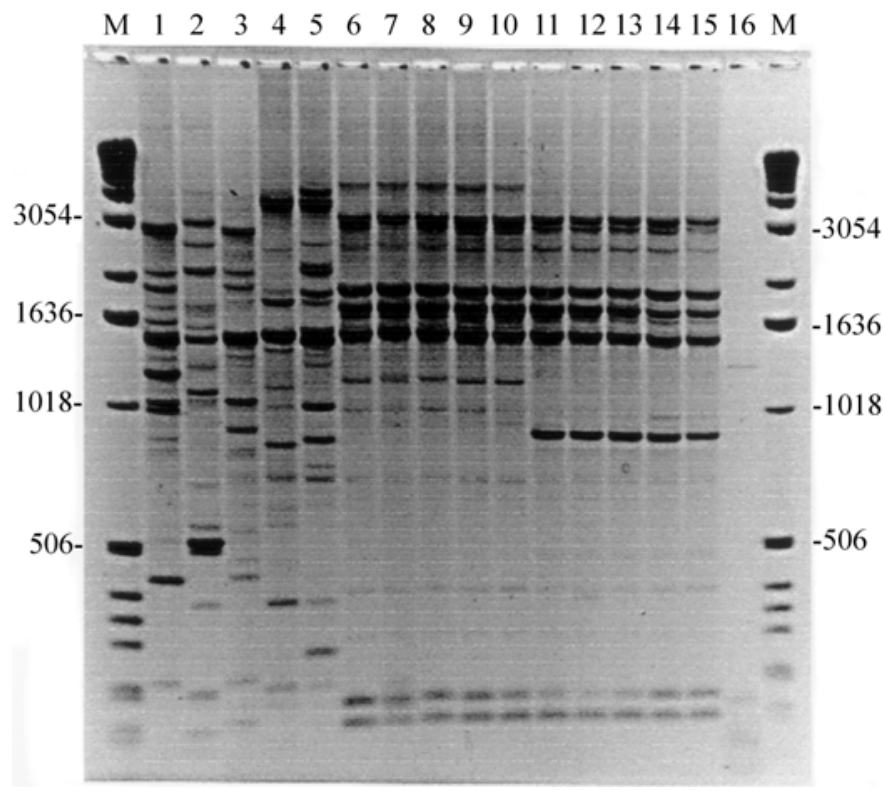

Fig. 2. Repetitive extragenic palindromic polymerase chain reaction genomic fingerprint patterns of Xanthomonas campestris pv. vesicatoria and $X$. campestris pv. vitians strains. Lanes $1-3, X$. campestris pv. vesicatoria strain 110c (Group A), strain 766a (Group B), and strain 762b (Group A), respectively; lane 4, Xanthomonas sp. B-53 (nonpathogenic strain); lane 5, $X$. campestris pv. vitians strain LMG 937; lanes 6-10, X. campestris pv. vitians Group A strains (700a, 700b, 700c, 705a, and 916); lanes 11-15, X. campestris pv. vitians Group B strains (LMG 938, B-58, B-59, 701a, and 701c); lane 16, negative control; and $\mathrm{M}=\mathrm{DNA}$ ladder (1kb). pathogenic on other lettuce cultivars, but given its phenotypic and genotypic differences with Group A and B strains and the lack of host-cultivar specificity exhibited among $X$. campestris pv. vitians strains in lettuce (16), this is not likely. It is interesting that strain B-53, which is similar to LMG 937 and recently isolated, was also nonpathogenic on lettuce. Thus, the association of these strains with lettuce may be valid but their ecological relevance is unclear.

Whether Group A and B strains represent different species is open to question. The taxonomy of Xanthomonas species in general and $X$. campestris and $X$. axonopodis in particular is being reevaluated $(20,25,29)$. Previous studies $(24,29)$ have not shown significant variation among $X$. campestris pv. vitians strains. However, these studies were performed with a relatively small number of strains, which were grouped together with the pathovar reference strain LMG 938. This strain was placed in Group B in this study. However, the majority of strains isolated in Ohio were

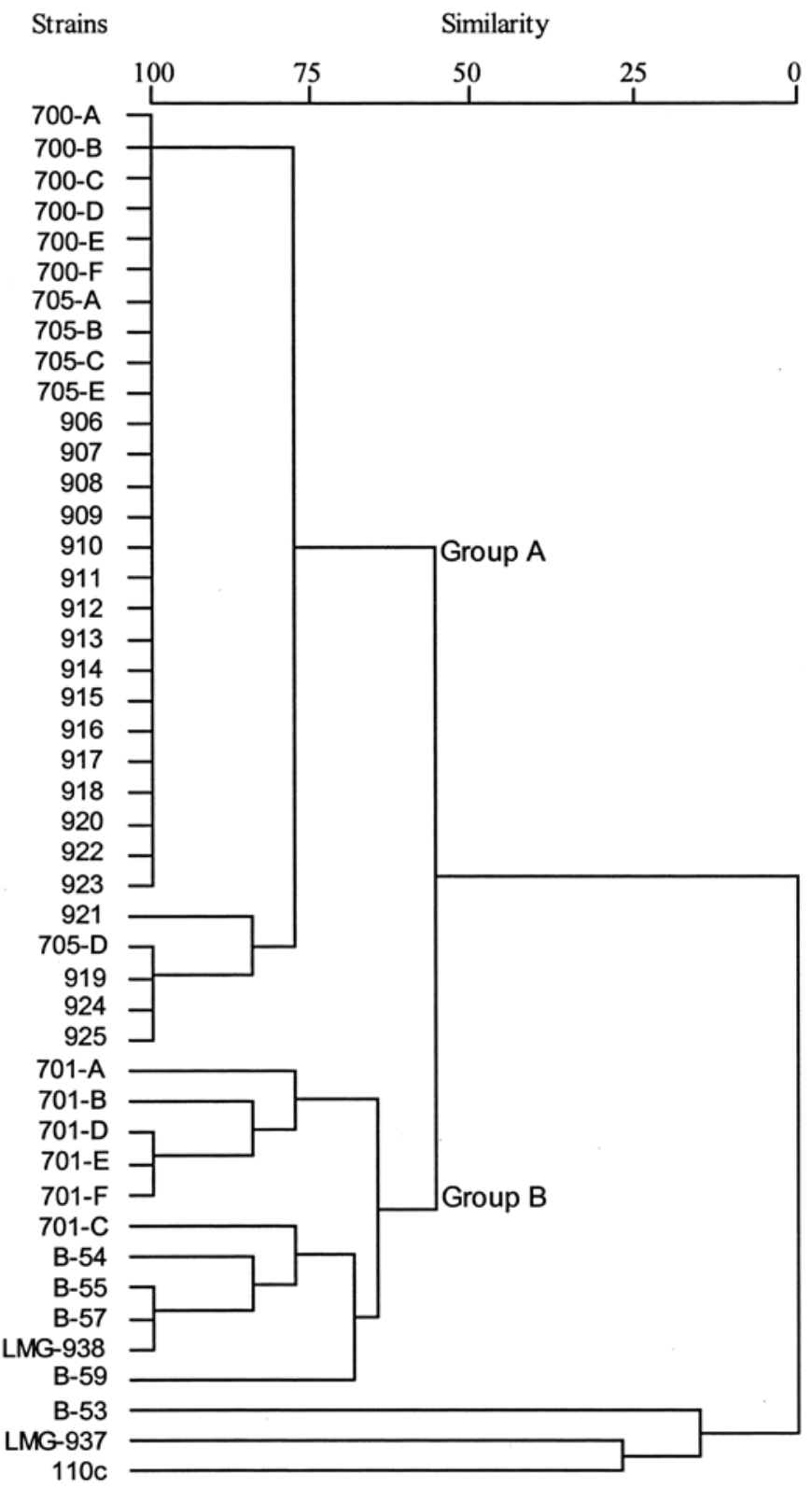

Fig. 3. Dendrogram derived by cluster analysis of similarities between Xanthomonas campestris pv. vitians strains based on enterobacterial repetitive intergenic consensus (ERIC), BOX, and repetitive extragenic palindromic (REP) polymerase chain reaction DNA genomic profiles. Analysis was performed with complete linkage and Euclidean distance options of Minitab statistical software version 13.0 (Minitab Inc., State College, PA). 
placed in Group A. While strains in both groups were aggressive on lettuce, the Group A strains may pose a more serious threat to lettuce production due to their systemic spread in the plant. Additional comparisons among strains from both groups are necessary to determine the taxonomic status of this pathovar. It was possible to distinguish $X$. campestris pv. vitians strains from several pathovars of Xanthomonas species causing diseases of vegetable crops.

The two pathogenicity Groups A and B of X. campestris pv. vitians could also be distinguished by serological profiles generated by monoclonal antibodies in indirect ELISA. Reactivity with a single antibody, Xv5, differentiated strains of Group A from Group B. In addition, X. campestris pv. vitians strains were clearly differentiated from other pathovars of $X$. campestris, indicating that ELISA, using the selected MAbs, is useful and reliable not only for characterization but also for identification of $X$. campestris pv. vitians strains.

The majority (59\%) of the $44 X$. campestris pv. vitians strains tested were not identified accurately at the pathovar level by Biolog profiles. This result confirmed a previous report (8) that identification of strains in different pathovars of $X$. campestris is difficult with the Biolog system due to the close relationship of those pathovars. Improvement of the current Biolog database by strengthening the library may help in use of this system for rapid and accurate identification of $X$. campestris pv. vitians strains in the future. The Biolog system has been used for characterization of $X$. campestris pv. vitians strains. Vauterin et al. (24) reported that two groups of $X$. campestris pv. vitians could be separated based on Biolog profiles and DNA hybridization data. They also proposed that these two groups should be reclassified as $X$. axonopodis pv. vitians and $X$. hortorum pv. vitians. Although they indicated that metabolic fingerprints obtained from the Biolog system could differentiate these proposed species, they did not name the differentially metabolized substrates. In our study, 10 of 95 carbon sources available in the Biolog system were useful for differentiation of the two distinct groups (A and B) of $X$. campestris pv. vitians. Two strains (LMG 937 and LMG 938) of $X$. campestris pv. vitians, defined as reference strains for the proposed species (24), X. axonopodis pv. vitians and $X$. hortorum pv. vitians, respectively, were included. LMG 937 could be distinguished from other strains of $X$. campestris pv. vitians based on utilization of the carbon sources: D-lactose, formic acid, glycyl-L-aspartic acid, L-threonine, and glycerol. Group A and B strains did not utilize these substrates. The other reference strain, LMG 938, was identified as a member of Group B. The differences between Group A and B strains were in the utilization of the substrate L-serine, which was metabolized by Group A but not Group B strains and the substrates $\alpha$-hydroxybutyric acid and $\alpha$ ketobutyric acid, which were utilized by Group B but not Group A strains. Therefore, these differential substrates can be used for characterization of $X$. campestris pv. vitians strains. In addition, it may be possible to develop selective media for detection and identification of $X$. campestris pv. vitians strains in two different groups by using these substrates as sole sources of carbon.

SDS-PAGE protein profile data confirmed previous results reporting the heterogeneity among $X$. campestris pv. vitians strains $(22,26)$. Observation of two different SDS-PAGE profiles provides further evidence supporting the existence of two distinct

\section{ClustalW Formatted Alignments}
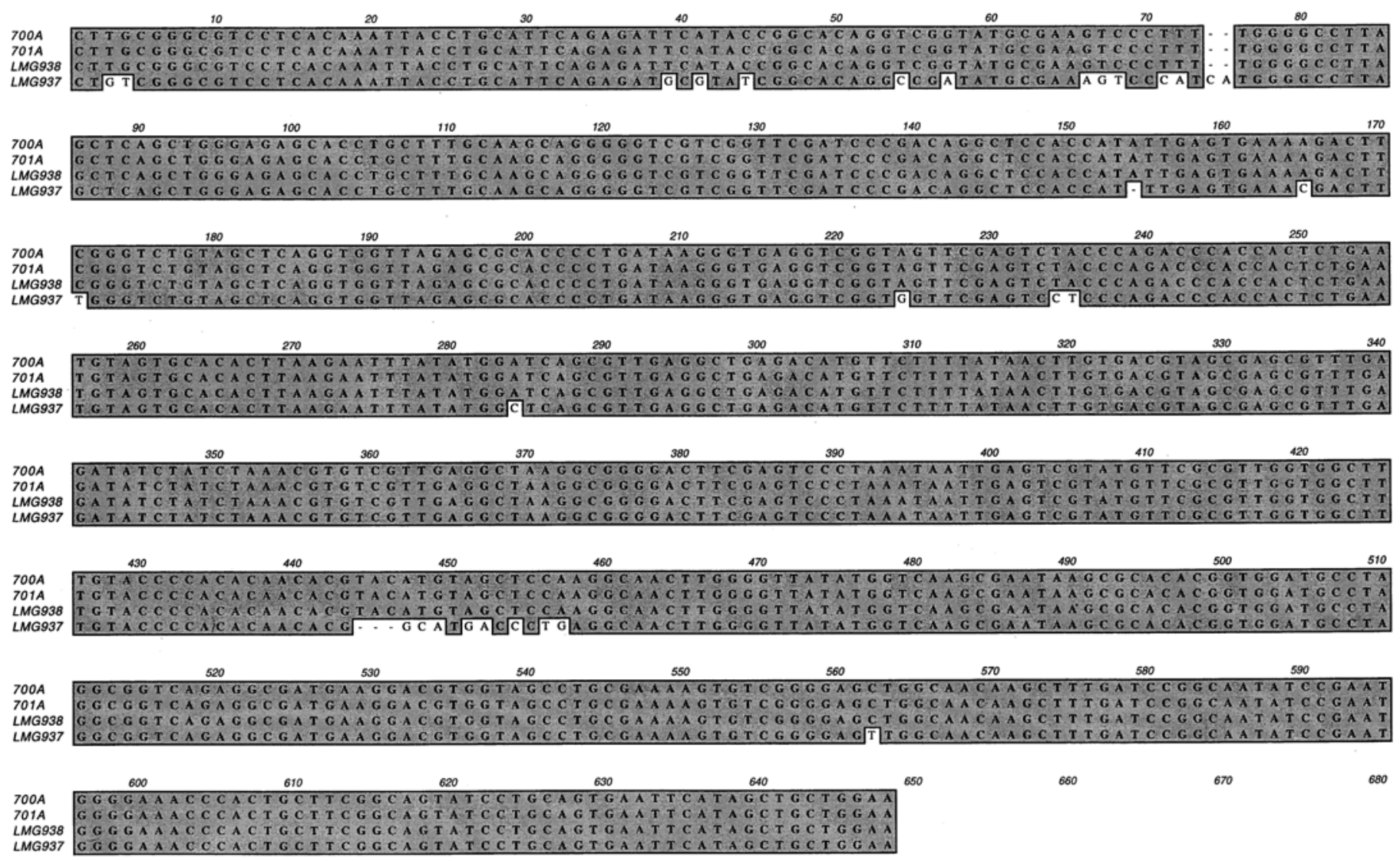

Fig. 4. ClustalW sequence alignment of a PCR-amplified DNA fragment from the 16S-23S rDNA spacer region of Xanthomonas campestris pv. vitians strain LMG 937 (type strain), and X. campestris pv. vitians strains 700a (Group A) and 701a (Group B). Sequence differences are unshaded, deletions are indicated by dashes, and $\mathrm{N}$ indicates an undetermined nucleotide. Two transfer RNA genes tRNA ${ }^{\text {Ala }}$ and tRNA ${ }^{\text {Ile }}$ are located within the spacer region between nucleotides 98 and 174 and 193 and 269, respectively. 
subgroups of $X$. campestris pv. vitians. Our results also showed that strains of $X$. campestris pv. vitians and $X$. campestris pv. vesicatoria displayed quite distinct protein profiles. These results suggest that protein profiling can be used for differentiation of these pathogens when they are isolated from the same host (pepper or tomato).

Rep-PCR analysis differentiated $X$. campestris pv. vitians Group A and B strains from each other and from the X. campestris pv. vesicatoria strains tested. Rep-PCR has been demonstrated to differentiate pathovars of $X$. campestris and other species of bacterial pathogens with a high degree of resolution (12-15); we have shown that it can be a useful and efficient diagnostic tool for lettuce pathogens as well. Sequence analysis of the 16S-23S spacer region did not differentiate $X$. campestris pv. vitians Groups A and B but did distinguish them from LMG 937. Published 16S-23S rDNA nucleotide sequences are readily available through GenBank, which may facilitate the development of specific PCR primers to differentiate $X$. campestris pv. vitians from other Xanthomonas species and $X$. campestris pathovars for routine diagnostic use.

\section{ACKNOWLEDGMENTS}

We thank M. Merighi and S. Kamoun who provided presubmission reviews. This research was supported by Ataturk University, Erzurum, Turkey, and State and Federal Funds appropriated to the Ohio Agricultural Research and Development Center (OARDC), The Ohio State University.

\section{LITERATURE CITED}

1. Altschul, S. F., Madden, T. L., Schaffer, A. A., Zhang, J. H., Zhang, Z., Miller, W., and Lipman, D. J. 1997. Gapped BLAST and PSI-BLAST: A new generation of protein database search programs. Nucleic Acids Res. 25:3389-3402.

2. Alvarez, A. M., Benedict, A. A., Mizumoto, C. Y., Hunter, J. E., and Gabriel, D. W. 1994. Serological, pathological and genetic diversity among strains of Xanthomonas campestris infecting crucifers. Phytopathology 84:1449-1457.

3. Bouzar, H., Jones, J. B., Stall, R. E., Hodge, N. C., Minsavage, G. V., Benedict, A. A., and Alvarez, A. M. 1994. Physiological, chemical, serological, and pathogenic analyses of a worldwide collection of Xanthomonas campestris pv. vesicatoria. Phytopathology 84:663-671.

4. Brosius, J., Dull, T. J., and Noller, H. F. 1980. Complete nucleotide sequence of a $23 \mathrm{~S}$ ribosomal RNA gene from Escherichia coli. Proc. Natl. Acad. Sci. USA 77:201-204.

5. Ewing, B., and Green, P. 1998. Base-calling of automated sequencer traces using Phred. II. Error probabilities. Genome Res. 8:186-194.

6. Ewing, B., Hillier, L., Wendl, M. C., and Green, P. 1998. Base-calling of automated sequencer traces using Phred. I. Accuracy assessment. Genome Res. 8:175-185.

7. Gurtler, V., and Stanisich, V. A. 1996. New approaches to typing and identification of bacteria using the 16S-23S rDNA spacer region. Microbiology 142:3-16.

8. Jones, J. B., Chase, A. R., and Harris, G. K. 1993. Evaluation of the Biolog GN microplate system for identification of some plant pathogenic bacteria. Plant Dis. 77:553-558.

9. Laguerre, G., Allard, M., Revoy, F., and Amarger, N. 1994. Rapid identification of Rhizobia by restriction fragment length polymorphism analysis of PCR-amplified 16S rRNA genes. Appl. Environ. Microbiol. 60:56-63.

10. Lelliot, R. A., and Stead, D. E. 1987. Methods for the Diagnosis of Bacterial Diseases of Plants. Blackwell Scientific Publications, Oxford.

11. Leyns, F., De Cleene, M., Swings, J. G., and De Ley, J. 1984. The host range of the genus Xanthomonas. Bot. Rev. 50:308-356.

12. Louws, F. J., Fulbright, D. W., Stephens, C. T., and de Bruijn, F. J. 1994. Specific genomic fingerprints of phytopathogenic Xanthomonas and Pseudomonas pathovars and strains generated with repetitive sequences and PCR. Appl. Environ. Microbiol. 60:2286-2295.

13. Louws, F. J., Fulbright, D. W., Stephens, C. T., and de Bruijn, F. J. 1995. Determination of genomic structure by rep-PCR fingerprinting to rapidly classify Xanthomonas campestris pv. vesicatoria. Phytopathology 85:528-536.

14. Opgenorth, D. C., Smart, C. D., Louws, F. J., de Bruijn, F. J., and Kirkpatrick, B. C. 1996. Identification of Xanthomonas fragariae field isolates by rep-PCR genomic fingerprinting. Plant Dis. 80:868-873.

15. Rademaker, J. W. L. 1999. Computer-assisted pattern analysis of repPCR genomic fingerprints in the molecular systematics of Xanthomonas. $\mathrm{Ph} . \mathrm{D}$. thesis. Universiteit Gent, Belgium.

16. Sahin, F., and Miller, S. A. 1997. Identification of the bacterial leaf spot pathogen of lettuce, Xanthomonas campestris pv. vitians in Ohio, and assessment of cultivar resistance and seed treatment. Plant Dis. 81:14431446.

17. Sahin, F., and Miller, S. A. 1998. Two new hosts of Xanthomonas campestris pv. vitians. Plant Dis. 82:262.

18. Sambrook, J., Fritsch, E. F., and Maniatis, T. 1989. Molecular Cloning: A Laboratory Manual. 2nd ed. Cold Spring Harbor Laboratory, Cold Spring Harbor, NY.

19. Sasser, M. 1990. Identification of bacteria through fatty acid analysis. Pages 199-204 in: Methods in Phytobacteriology. Z. Klement, K. Rudolph, and D. Sands, eds. Akademiai Kiado, Budapest.

20. Schaad, N. W., Vidaver, A. K., Lacy, G. H., Rudolph, K., and Jones, J. B. 2000. Evaluation of proposed amended names of several pseudomonads and xanthomonads and recommendations. Phytopathology 90:208-213.

21. Stall, R. E., Beaulieu, C., Egel, D., Hodge, N. C., Leite, R. P., Minsavage, G. V., Bouzar, H., Jones, J. B., Alvarez, A. M., and Benedict, A. A. 1994. Two genetically diverse groups of strains are included in a pathovar of Xanthomonas campestris pv. vesicatoria. Int. J. Syst. Bacteriol. 44:47-53.

22. Stefani, E., Raio, A., Bazzi, C., and Zoina, A. 1994. Identification of Xanthomonas campestris pv. vitians using SDS-PAGE. Phytopathol. Mediterr. 33:99-104.

23. Swings, J. G., and Civerolo, E. L. 1993. Xanthomonas. Chapman and Hall, London.

24. Vauterin, L., Hoste, B., Kersters, K., and Swings, J. 1995. Reclassification of Xanthomonas. Int. J. Syst. Bacteriol. 45:472-489.

25. Vauterin, L., Rademaker, J., and Swings, J. 2000. Synopsis of the taxonomy of the genus Xanthomonas. Phytopathology 90:677-682.

26. Vauterin, L., Swings, J., and Kersters, K. 1991. Grouping of Xanthomonas campestris pathovars by SDS-PAGE of proteins. J. Gen. Microbiol. 137:1677-1687.

27. Vauterin, L., Yang, P., and Swings, J. 1996. Utilization of fatty acid methyl esters for the differentiation of new Xanthomonas species. Int. J. Syst. Bacteriol. 46:298-304.

28. Vera Cruz, C. M., Gossele, F., Kersters, K., Segers, P., Van den Mooter, M., Swings, J., and De Ley, J. 1984. Differentiation between Xanthomonas campestris pv. oryzae, Xanthomonas campestris pv. oryzicola and the "brown blotch" pathogen on rice by numerical analysis of phenotypic features and protein electrophoresis. J. Gen. Microbiol. 130:29832999.

29. Yang, P., Vauterin, L., VanCanneyt, M., Swings, J., and Kersters, K. 1993. Application of fatty acid methyl esters for the taxonomic analysis of the genus Xanthomonas. Syst. Appl. Microbiol. 16:47-71. 